\title{
Xenogeneic Humoral Immune Responses to Human Mesenchymal Stem Cells in Mice
}

\author{
Jun-Man Hong ${ }^{1}$, Jin-Hee Kim ${ }^{4,6}$, Gwang-Hoon Kim ${ }^{1,2,3}$, Hyun-Mu Shin ${ }^{2,3,5}$, Young-il Hwang ${ }^{1}$ \\ ${ }^{I}$ Department of Anatomy and Cell Biology, Seoul National University College of Medicine, Seoul, Korea \\ ${ }^{2}$ Department of Biomedical Sciences, Seoul National University College of Medicine, Seoul, Korea \\ ${ }^{3}$ BK21FOURs Biomedical Science Project, Seoul National University College of Medicine, Seoul, Korea \\ ${ }^{4}$ Medical Research Institute, Seoul National University College of Medicine, Seoul, Korea \\ ${ }^{5}$ Wide River Institute of Immunology, Seoul National University, Hongcheon, Korea \\ ${ }^{6}$ Department of Biomedical Laboratory Science, College of Health Science, Cheongju University, Cheongju, Korea
}

Background and Objectives: Many preclinical studies have been conducted using animal disease models to determine the effectiveness of human mesenchymal stem cells (hMSCs) for treating immune and inflammatory diseases based on the belief that hMSCs are not immunogenic across species. However, several researchers have suggested xenogeneic immune responses to hMSCs in animals, still without detailed features. This study aimed to investigate a xenogeneic humoral immune response to hMSCs in mice in detail.

Methods and Results: Balb/c mice were intraperitoneally injected with adipose tissue-derived or Wharton's jelly-derived hMSCs. Sera from these mice were titrated for each isotype. To confirm specificity of the antibodies, hMSCs were stained with the sera and subjected to a flow cytometic analysis. Spleens were immunostained for proliferating cell nuclear antigen to verify the germinal center formation. Additionally, splenocytes were subjected to a flow cytometric analysis for surface markers including GL-7, B220, CD4, CD8, CD44, and CD62L. Similar experiments were repeated in $\mathrm{C} 57 \mathrm{BL} / 6$ mice. The results showed increased $\mathrm{IgG}_{1}$ and $\mathrm{IgG}_{2 \mathrm{a}}$ titers in the sera from Balb/c mice injected with $\mathrm{hMSCs}$, and the titers were much higher in the secondary sera than in the primary sera. These antibodies were specifically stained the hMSCs. Germinal centers were observed in the spleen, and flow cytometric analysis of the splenocytes showed higher frequencies of centroblasts $\left(\mathrm{B} 220^{+} \mathrm{GL7}^{+}\right)$and memory $\mathrm{T}$ cells $\left(\mathrm{CD} 62 \mathrm{~L}^{+} \mathrm{CD} 44^{+}\right)$both in $\mathrm{CD} 4^{+}$and $\mathrm{CD} 8^{+}$subsets. Similar results were obtained for C57BL/ 6 mice.

Conclusions: hMSCs induced a humoral immune response in mice, with characters of $\mathrm{T}$ cell-dependent immunity.

Keywords: Human mesenchymal stem cells, Adipose tissue-derived, Wharton's jelly-derived, Xenogeneic immune response, Humoral immune response, $\mathrm{T}$ cell-dependent immunity

Received: June 24, 2021, Revised: October 8, 2021,

Accepted: October 16, 2021, Published online: December 31, 2021 Correspondence to Young-il Hwang

Department of Anatomy and Cell Biology, Seoul National University College of Medicine, 103 Daehak-ro, Jongno-gu, Seoul 03080, Korea Tel: +82-2-740-8209, Fax: +82-2-745-9528

E-mail: hyi830@snu.ac.kr

(c) This is an open-access article distributed under the terms of the Creative Commons Attribution Non-Commercial License (http://creativecommons.org/ licenses/by-nc/4.0/), which permits unrestricted non-commercial use, distribution, and reproduction in any medium, provided the original work is properly cited.

Copyright (c) 2022 by the Korean Society for Stem Cell Research

\section{Introduction}

As multipotent, self-renewing adult stem cells, mesenchymal stem cells (MSCs) can differentiate into a variety of specialized tissue cells such as chondrocytes (1), osteocytes (2), hepatocytes (3), and neuronal cells (4), which warrants the application of these cells in regenerative medicine. Besides, MSCs also have been considered to be used in the treatment of chronic inflammatory or immune diseases such as graft-versus-host disease (5), rheumatoid arthritis (6), chronic colitis (7), and so on, because they 
exert anti-inflammatory and immunosuppressive activities (8).

In addition to the above-mentioned diseases, many experiments have been performed using animal disease models for many other disorders, including stroke, diabetes mellitus, septic shock, and kidney diseases. Human MSCs (hMSCs), which are xenogeneic to experimental animals, have frequently been used in many experiments to elucidate the role of hMSCs in disease, based on the belief that MSCs are not immunogenic across species; successful immunosuppressive and anti-inflammatory effects were reported (9).

However, the possibility that the exogenous MSCs, either allogeneic or xenogeneic, could yield host immune responses has been suggested (10), and some investigators have reported xenogeneic immune response to hMSCs. Specifically, when peripheral blood mononuclear cells were isolated from horses injected intra-articularly with hMSCs and co-cultured with hMSCs, cell-mediated immunity occurred with increases in the $\mathrm{CD} 4^{+} \mathrm{T}$ cells number and IL-6 concentration in the supernatant (11). Similar results were reported in ischemic heart model rats (12), both of which implied the provocation of a cellular immune response against hMSCs. Recently, Hwang et al. (13) observed that intra-cerebral injection of hMSCs induced high infiltration of CD45-positive leukocytes and argued that xenogeneic MSCs were "not poorly immunogenic" as previously noted. Concerning the humoral immune response, the sera obtained from female NZB/NZW F1 mice, a representative animal model for lupus, which were repeatedly injected with hMSCs stained positive for hMSCs based on flow cytometric analysis (14), indicating the occurrence of a humoral immune response. However, no further details have been reported.

In the present study, we clearly identified the presence of a humoral immune response against hMSCs in mice, a representative human disease model, and further characterized it in detail.

\section{Materials and Methods}

\section{Experimental animals}

Male Balb/c and C57BL/6 (B6) mice 6 7 weeks of age were purchased from OrientBio (Seongnam, Republic of Korea). The animals were kept at the animal facility of Seoul National University College of Medicine under specific-pathogen-free conditions. All animal experiments were approved by the IACUC of Seoul National University (SNU-170612-2).

\section{Human mesenchymal stem cells (hMSCs)}

Two types of hMSCs were used in the present study. Adipose tissue-derived MSCs (Ad-MSCs) were prepared and characterized as described previously (15). Briefly, $450 \mathrm{ml}$ MSC basal medium (Lonza, Walkerville, MD, USA) was supplemented with $50 \mathrm{ml}$ mesenchymal cell growth supplement (Lonza), $10 \mathrm{ml} \mathrm{L-glutamine} \mathrm{(Lonza),}$ and $0.5 \mathrm{ml}$ gentamicin sulfate $(30 \mathrm{mg} / \mathrm{ml})$ and amphotericin-B (15 $\mu \mathrm{g} / \mathrm{ml})$ mixture (GA-1000, Lonza), and used for Ad-MSC culture. Wharton's jelly-derived MSCs (UC-MSCs) were gifted by professor Jo et al. (16) and maintained in low-glucose DMEM (Hyclone, South Logan, UT, USA) supplemented with $10 \%$ fetal bovine serum (Hyclone), $100 \mathrm{U} / \mathrm{ml}$ penicillin, $100 \mu \mathrm{g} / \mathrm{ml}$ streptomycin, and $0.25 \mu \mathrm{g} / \mathrm{ml}$ amphotericin (Welgene Inc., Gyeongsan, South Korea).

Characterization of the MSCs were performed previously for the expression of surface markers including CD29, CD34, CD44, CD45, CD90, CD105, and CD117 and for the lineage differentiation capacity to adipocytes, chondrocyes, and osteoblasts in our previous experiments using the same stalk of MSCs to this experiment $(15,17$, 18 for Ad-MSCs and 18 for UC-MSCs), the results of which indicated that the cells were mesenchymal stem cells. For this experiment, frozen stalks of these cells from passage $5 \sim 6$ were thawed, plated at a cell density of $1 \times 10^{6}$ cells/T75 flask, and cultured until sub-confluency when the cells were harvested with trypsinization and prepared for injection.

Mice were injected intraperitoneally on days 1 and 31 with $1 \times 10^{6}$ naïve or activated Ad-MSCs or UC-MSCs from passage $7 \sim 8$ in $100 \mu 1$ PBS. Sera were obtained on days 0,10 , and 38 from the orbital plexus under anesthesia, and the mice were sacrificed on day 38. The number of mice in each experimental group was eight. Another eight mice of the same age were used as the control group, which were injected only with PBS. For activation, hMSCs were treated with $10 \mathrm{ng} / \mathrm{ml}$ human IFN- $\gamma$ (PeproTech, Rocky Hill, NJ, USA) for $72 \mathrm{~h}$. The study protocol was approved by the Institutional Review Board of Seoul National University (SNU-J-1511-005-715).

\section{Enzyme-linked immunosorbent assay (ELISA)}

The antibody titer in the serum was measured using ELISA. The 96-well ELISA plate was coated with goat anti-mouse total immunoglobulin (Ig; M6149, Sigma, St. Louis, MO, USA) at $3.75 \mu \mathrm{g} / 100 \mu 1$ PBS per well and then blocked in $1 \%$ skim milk. Serum samples were duplicated, serially diluted four-fold, and incubated for $2 \mathrm{~h}$ at room temperature (RT). Then, the plate was incubated 
with alkaline phosphatase-conjugated secondary antibodies at a $1: 1,000$ dilution $(0.5 \sim 1 \mu \mathrm{g} / 100 \mu 1$ PBS per well) for $1 \mathrm{~h}$ at RT, followed by a color reaction with $1 \mathrm{mg} / \mathrm{ml}$ p-nitrophenyl phosphate substrate (Sigma). The absorbance was measured at $405 \mathrm{~nm}$ using a spectrophotometer (Molecular Devices Co., Sunnyvale, CA, USA). The antibody titers in the serum were calculated relative to the values in a standard serum sample drawn from mice secondarily immunized with Keywhole limpet hemocyanin (KLH) in a previous study. In the B6 sera, $\operatorname{IgG}_{2 c}$ instead of $\operatorname{IgG}_{2 a}$ titers were measured (19). For the measurement of absolute concentrations of $\operatorname{IgG}_{1}$ and $\operatorname{IgG}_{2 a}$, standards of known concentration were used: mouse $\operatorname{IgG}_{1}$, kappa (MOPC 21, Sigma, M-9269; $1 \mathrm{mg} / \mathrm{ml}$ ) and anti-p-ERK (E-4) mouse monoclonal $\mathrm{IgG}_{2 \mathrm{a}}$ (Santa Cruz, SC-7383; $200 \mu \mathrm{g} / \mathrm{ml}$ ). The secondary antibodies used were as follows: goat antimouse Ig $(\mathrm{H}+\mathrm{L})$ (1010-04), $\operatorname{IgG}_{1}$ (1070-04), IgG $\operatorname{Ig}_{2 \mathrm{a}}(1080-04)$, $\mathrm{IgG}_{2 \mathrm{~b}}$ (1090-04), IgG $\mathrm{Ig}_{2 \mathrm{c}}$ (1079-04), IgG $(1100-04)$, and IgM (1020-04) (all from Southern Biotech, Birmingham, AL, USA).

\section{Immunostaining of the spleen for proliferating cell nuclear antigen (PCNA)}

Half of the spleen obtained at the time of sacrifice was fixed in methacarn solution (methanol : chloroform : acetic acid=6:3:1) for $24 \mathrm{~h}$, processed, and embedded in paraffin. Samples were sliced into $4-\mu \mathrm{m}$ thick sections, deparaffinized, and treated with $3 \% \mathrm{H}_{2} \mathrm{O}_{2}$ (in methanol) for $15 \mathrm{~min}$ to block endogenous peroxidases. Sections were incubated with biotinylated anti-mouse PCNA antibody (BioLegend, San Diego, CA, USA; $1: 100$ dilution) overnight at $4^{\circ} \mathrm{C}$ and then avidin-biotinylated HRP complex (Elite/Vectastain ABC kit, PK6100, Vector Laboratories, Burlingame, CA, USA; $1: 50$ dilution) for $1 \mathrm{~h}$ at RT. The color reaction was performed using 3,3'-diaminobenzidine (D8001, Sigma) for $5 \mathrm{~min}$ at RT.

\section{Flow cytometric analysis}

The other half of the spleen was minced using ground glasses. The cells were treated with RBC lysis buffer (Sigma) and washed twice with PBS to obtain the splenocytes. Cells were stained with $1: 200$ dilutions of Alexa647-anti-GL7 (561529), Bv786-anti-B220 (563894), Bv650-anti-CD4 (563232), APC-cy7-anti-CD8 (561967), PE-CD44 (553134) and/or Bv421-anti-CD62L (562910) antibodies (all from BD Biosciences, San Jose, CA, USA) for $30 \mathrm{~min}$ at $4^{\circ} \mathrm{C}$ and subjected to flow cytometric analysis using LSRFortessa (BD Biosciences).

To confirm the presence of antibodies specific to hMSCs, naïve or activated UC-MSCs or Ad-MSCs were in- cubated with sera from each experimental group at a dilution of $1: 100$ or $1: 1,000$ for $1 \mathrm{~h}$, at $4^{\circ} \mathrm{C}$, and then with Alexa488-goat anti-mouse IgG antibody (Invitrogen, Camarillo, CA, USA; $1: 200$ dilution). The stained cells were analyzed on the BD LSRFortessa ${ }^{\mathrm{TM}}$ (BD Biosciences) instrument using FACSDiva ${ }^{\mathrm{TM}}$ software, and the data were analyzed using FlowJo ${ }^{\circledR}$ software (TreeStar, Ashland, OR, USA).

\section{Statistical analysis}

Statistical analysis was performed using the KruskalWallis $\mathrm{H}$ test and Dunn's multiple comparison test with SPSS 12.0 for Windows (SPSS, Chicago, IL, USA). A p-value $\leq 0.05$ was considered to indicate statistical significance.

\section{Results}

Antibody titrer in the sera from mice injected with hMSCs was increased, mainly due to the increase of $\lg G_{1}$ and $\lg _{2 a}$ sotype titers

In sera of Balb/c mice obtained 10 days after the first injection of hMSCs (i.e., primary serum), the total Ig titer was increased in all experimental groups (Fig. 1), even though only the naive Ad-MSC-injected group secured statistical significance compared to the control group. This increase was due mainly to increased $\operatorname{IgG}_{1}$ and $\operatorname{IgG}_{2 a}$ titers. $\operatorname{IgG}_{2 b}$ and $\operatorname{IgG}_{3}$ titers in the experimental groups did not change compared with the control. The IgM titer was decreased compared with the control but not significantly.

After the second injection, the serum (i.e., secondary serum) total Ig titer was increased (Fig. 2A). Similar to the primary serum, this was due to increases in the $\operatorname{IgG}_{1}$ and $\mathrm{IgG}_{2 \mathrm{a}}$ titers, and the other isotype antibodies did not show any significant changes (data not shown). The absolute concentrations of the $\operatorname{IgG}_{2 a}$ and $\operatorname{IgG}_{1}$ titers were increased approximately 6- and 54-fold, respectively, compared with the control (Fig. 2B, Table 1).

\section{The sera from mice injected with hMSCs surface-stained the hMACs}

Even though the titers of total $\mathrm{Ig}, \mathrm{IgG}_{1}$, and $\operatorname{IgG}_{2 \mathrm{a}}$ were increased in all experimental groups compared to the control group, some lacked statistical significance. Thus, we need to verify whether specific antibodies to the injected hMSCs were developed in the mice. For this purpose, we stained hMSCs with the secondary sera from each experimental group and analyzed using flow cytometry. The sera from all experimental groups were positive for both UC-MSCs and Ad-MSCs, irrespective of naïve or activated (Fig. 3). Meanwhile, the control sera minimally stained the 

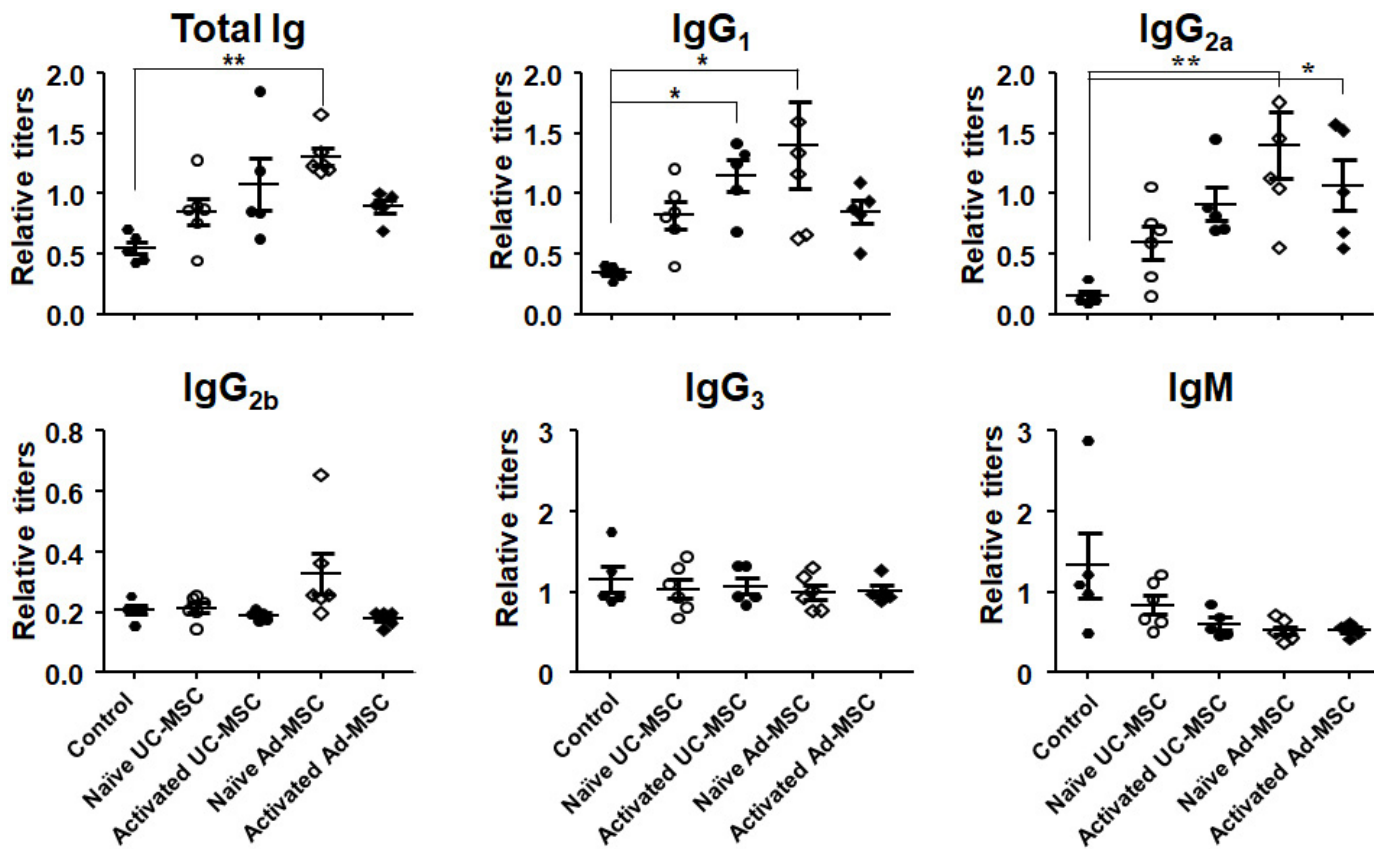

$\lg M$

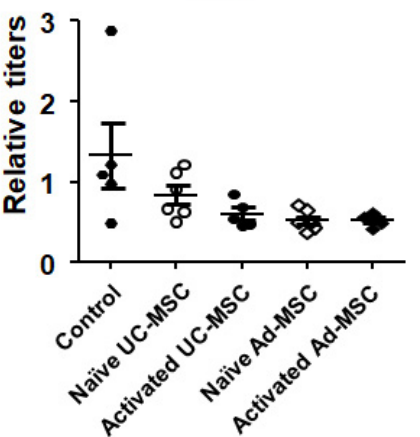

Fig. 1. Elevated serum immunoglobulin titers after primary injection of human MSCs. Mouse blood was drawn 10 days after intraperitoneal injection of human MSCs and sera were obtained. Titration was done by ELISA using a standard serum which had been drawn from secondarily immunized mice with $\mathrm{KLH}$ in previous studies. ${ }^{*} \mathrm{p}<0.05$ and ${ }^{* *} \mathrm{p}<0.01$ vs. the control.

A
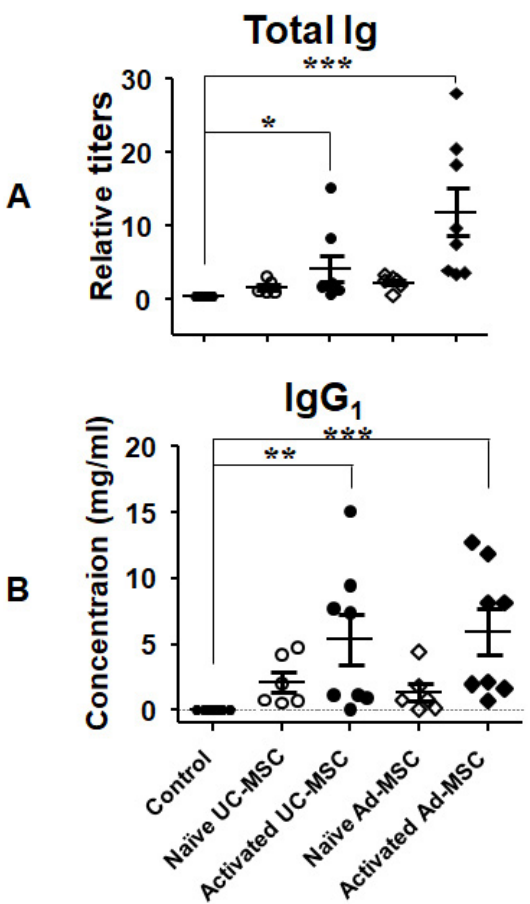
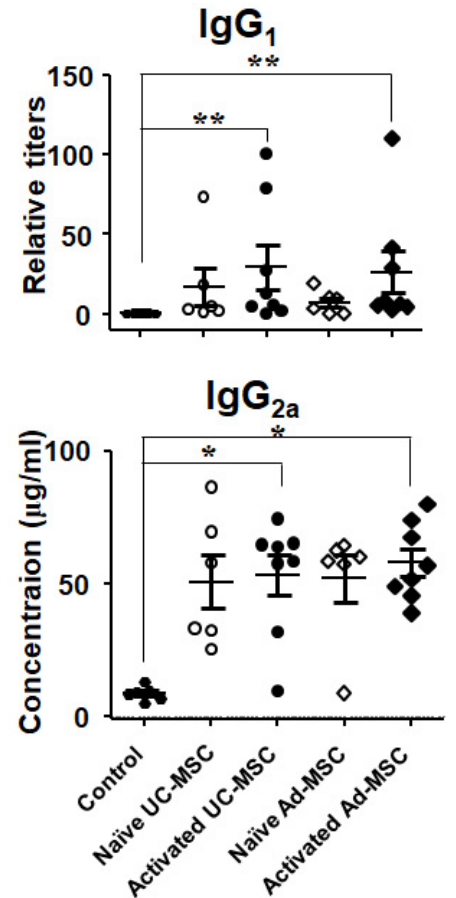
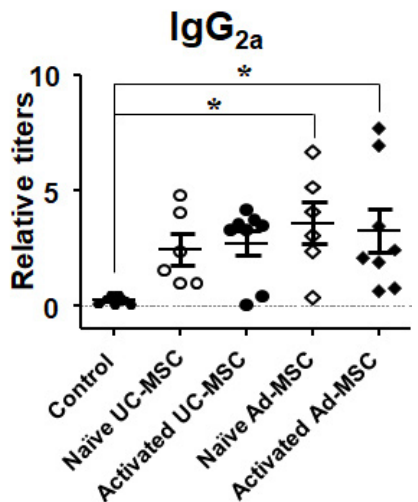

Fig. 2. Elevated serum immunoglobulin titers after secondary injection of human MSCs. Mice were injected with human MSCs on days 1 and 31, and blood samples were obtained seven days after the second injection. ELISA was performed with each sample duplicated using (A) $\mathrm{KLH}$-immunized serum or (B) purified mouse $\lg \mathrm{G}_{1}$ or $\operatorname{lgG}_{2 \mathrm{a}}$ antibodies of known concentration as a standard. ${ }^{*} \mathrm{p}<0.05,{ }^{* *} \mathrm{p}<0.01$, and $* * * \mathrm{p}<0.001$ vs. the control. 
Table 1. Absolute concentrations of Ig isotypes in the secondary sera of Balb/c mice

\begin{tabular}{lcccccc}
\hline & Control & nUC-MSC & aUC-MSC & nAd-MSC & aAd-MSC \\
\hline $\operatorname{lgG}_{1} \mu \mathrm{g} / \mathrm{ml}$ (fold increase) & 23.9 & $2158.5(90.3)$ & $5343.2(223.6)$ & $1303.6(54.5)$ & $5958.1(249.3)$ \\
$\operatorname{lgG}_{2 a}$ & $\mu \mathrm{g} / \mathrm{ml}$ (fold increase) & 8.9 & $50.8(5.7)$ & $53.2(6.0)$ & $51.9(5.8)$ & $58.1(6.5)$ \\
\hline
\end{tabular}

nUC-MSC: naïve UC-MSC, aUC-MSC: activated UC-MSC, nAd-MSC: naïve Ad-MSC, aAd-MSC: activated Ad-MSC.

A Naïve UC-MSC-

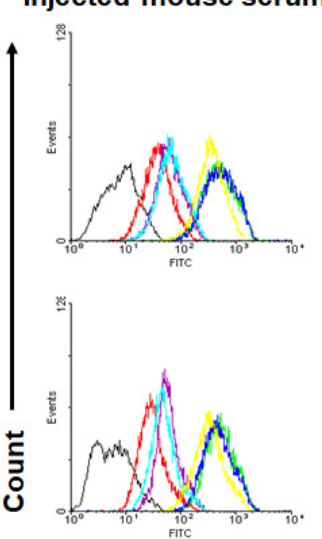

Anti-mouse IgG-FITC
Activated UC-MSC-

injected mouse serum
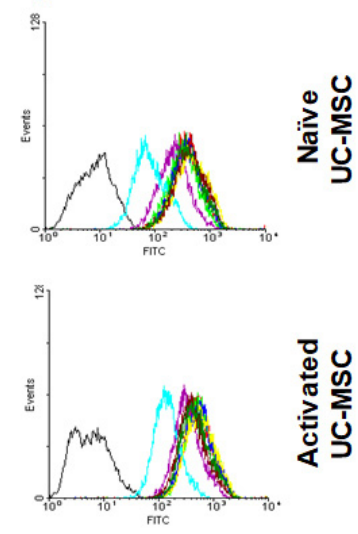

B

Naïve Ad-MSCinjected mouse serum

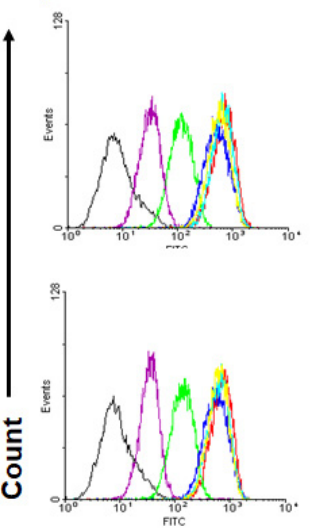

Anti-mouse IgG-FITC
Activated Ad-MSC-

injected mouse serum

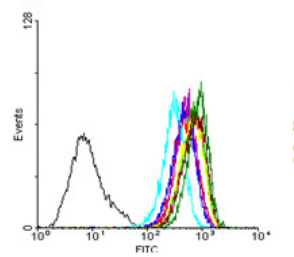

:
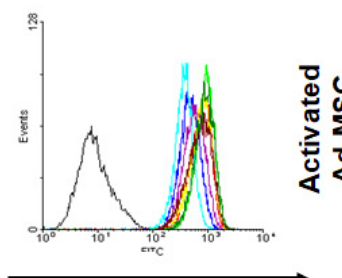

Fig. 3. Surface staining of human MSCs using mice sera. Human UC-MSCs, either naïve or activated, were stained with secondary sera from mice injected with naïve or activated hUC-MSCs (A). Likewise, hAd-MSCs, either naïve or activated, were stained with secondary sera from mice injected with naïve or activated hAd-MSCs (B). Stained cells were analyzed by flow cytometry. Colored graphs represent those stained with each serum, and the black one represents that stained only with a secondary serum. The mean median fluorescent intensity (MFI) values are summarized in Table 2.

Table 2. Median fluorescent intensity (MFI) values

\begin{tabular}{rlccccc}
\hline & & \multicolumn{2}{c}{ Stained cells } & \multicolumn{1}{c}{ Ratio } \\
\cline { 3 - 5 } & & nUC-MSCs & aUC-MSCs & nAd-MSCs & aAd-MSCs & \\
\hline Sera from mice & nUC-MSCs $(\mathrm{n}=6)$ & $252.8( \pm 222.1)$ & $243.1( \pm 223.5)$ & - & - & $90.3( \pm 11.6)$ \\
injected with... & aUC-MSCs $(\mathrm{n}=8)$ & $323.0( \pm 121.5)$ & $449.5( \pm 145.9)$ & - & - & $143.2( \pm 24.8)$ \\
& nAd-MSCs $(\mathrm{n}=6)$ & - & - & $412.6( \pm 272.1)$ & $427.6( \pm 271.8)$ & $106.6( \pm 7.1)$ \\
& aAd-MSCs $(\mathrm{n}=8)$ & - & - & $553.7( \pm 157.8)$ & $660.0( \pm 181.3)$ & $120.4( \pm 16.9)$ \\
\hline
\end{tabular}

Numbers are mean \pm SD.

nUC-MSC: naïve UC-MSC, aUC-MSC: activated UC-MSC, nAd-MSC: naïve Ad-MSC, aAd-MSC: activated Ad-MSC.

cells (Supplementary Fig. S1), which indicated the specificity of the staining by the experimental sera. Notably, although sera from mice injected with naïve hMSCs showed similar staining intensities between naïve and activated hMSCs, sera from mice injected with activated hMSCs showed more intense staining in the activated than naive cells (Table 2). This tendency was more prominent in the UC-MSC-injected groups (143.2\% in UC-MSCs, $\mathrm{p}=0.046$; $120.4 \%$ in Ad-MSCs, $\mathrm{p}=0.208)$.
Germinal centers were generated in the spleen as revealed by immunostaining for PCNA and FACS analysis of the splenocytes for their surface markers

In addition to the increase of serum antibody titers, immunohistochemical staining of PCNA, which is present in dividing cells, in the spleen showed germinal centers in hMSC-injected Balb/c mice (Fig. 4). However, no difference in the frequency of germinal centers between the Ad-MSC- and UC-MSC-injected groups was observed. In addition, flow cytometric analysis of splenocytes showed 

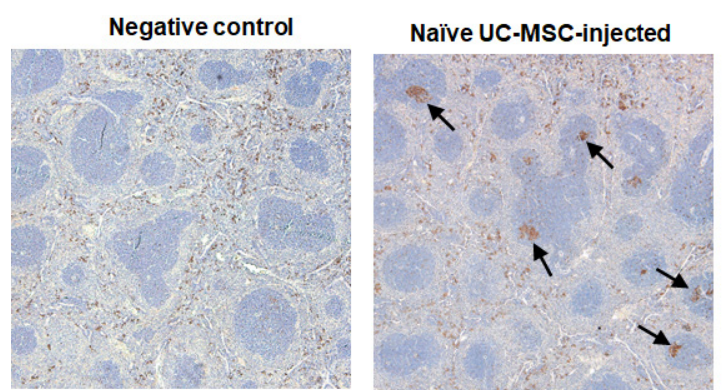

Naïve Ad-MSC-injected

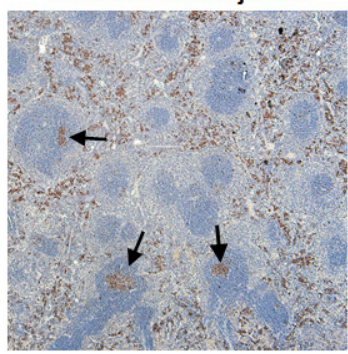

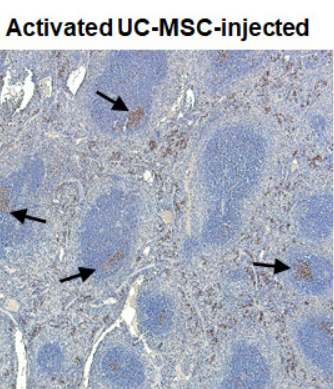

Activated Ad-MSC-injected

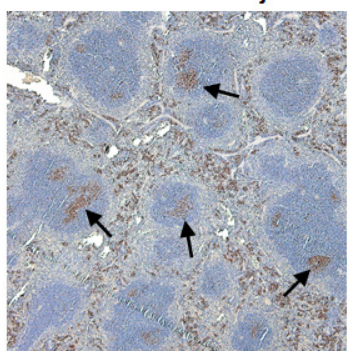

Fig. 4. Germinal center formation in the mouse spleen. Spleens from each group of second injection experiment were immuno-stained for proliferating cell nuclear antigen, which stained proliferating $B$ cells in the germinal centers. All the spleens show germinal centers (arrows), but no differences in the frequency were observed among groups. Magnification; $\times 100$.

Table 3. Relative concentrations of Ig isotypes in the sera of B6 mice

\begin{tabular}{lllllll}
\hline & & Control & nUC-MSC & aUC-MSC & nAd-MSC & aAd-MSC \\
\hline $\operatorname{lgG}_{1}$ & Ratio to standard (fold increase) & 0.304 & $0.804(2.6)$ & $1.082(3.6)$ & $1.743(5.7)$ & $2.186(7.2)$ \\
$\operatorname{lgG}_{2 c}$ & Ratio to standard (fold increase) & 0.296 & $0.903(3.1)$ & $1.04(3.5)$ & $0.994(3.4)$ & $3.027(10.2)$ \\
\hline
\end{tabular}

nUC-MSC: naïve UC-MSC, aUC-MSC: activated UC-MSC, nAd-MSC: naïve Ad-MSC, aAd-MSC: activated Ad-MSC.

an increased frequency of $\mathrm{GL}^{+}$germinal center B cells at the time of sacrifice (Supplementary Fig. S2). In both $\mathrm{CD}^{+}{ }^{+}$and $\mathrm{CD}^{+}{ }^{+} \mathrm{T}$ cells, the frequencies of effector $\left(\mathrm{CD} 62 \mathrm{~L}^{-}\right.$ $\left.\mathrm{CD}_{4}{ }^{+}\right)$and memory cells $\left(\mathrm{CD} 62 \mathrm{~L}^{+} \mathrm{CD} 44^{+}\right)$were increased (Supplementary Fig. S3 and S4). However, no difference was observed between the Ad-MSC- and UC-MSC-injected groups.

\section{Similar results were obtained from C57BL/6 mice}

In addition to Balb/c mice, similar experiments were performed in B6 mice; however, only secondary sera were analyzed. ELISA showed increased titers of total $\mathrm{Ig}, \mathrm{IgG}_{1}$, and $\mathrm{IgG}_{2 \mathrm{c}}$ in all groups compared with the control, similar to the $\mathrm{Balb} / \mathrm{c}$ mice. The titers of both isotypes were increased similarly compared with the control (Table 3). In contrast to the $\mathrm{Blab} / \mathrm{c}$ mice, the $\operatorname{IgM}$ titer was also increased in all experimental groups (Fig. 5). The sera stained hMSCs similar to the sera from Balb/c mice.

\section{Discussion}

In the present study, it was investigated whether hMSCs elicit xenogeneic humoral immune responses when in- jected into mice. In Balb/c mice, injection of hMSCs increased the $\operatorname{IgG}_{1}$ and $\operatorname{IgG}_{2 a}$ titers, which were higher in the secondary sera than in the primary sera. The sera stained hMSCs, as revealed by flow cytometric analysis, indicating that the increased antibodies were specific to hMSCs. Additionally, the frequency of $\mathrm{GL}^{+}$centroblasts and PCNA immunostaining showed germinal center formation in the spleen. When the same experiments were performed in $\mathrm{B} 6$ mice, similar results were obtained.

Both in Balb/c and B6 mice, $\operatorname{IgG}_{1}$ and $\operatorname{IgG}_{2 \mathrm{a}}\left(\mathrm{IgG}_{2 \mathrm{c}}\right.$ instead of $\operatorname{IgG}_{2 a}$ in $\mathrm{B} 6$ mice) were increased among the Ig isotypes evaluated. However, a difference in the profiles was observed between the two strains. In the secondary sera of Balb/c mice, the $\operatorname{IgG}_{1}$ titer increased significantly more, from 54- to 250-fold relative to the control group, than did the $\mathrm{IgG}_{2 \mathrm{a}}$ titer (approximately 6-fold) (Table 1). However, the fold increases in the two isotypes were similar in B6 mice (Table 3). It is well known that IFN- $\gamma$, a Th1 type cytokine, and IL-4, a Th2 type cytokine, reciprocally drive the production of $\operatorname{IgG}_{2 \mathrm{a}}$ and $\mathrm{IgG}_{1}$; thus the isotypes represent Th1 and Th2 humoral immune responses, respectively (20). Also known is that $\mathrm{Balb} / \mathrm{c}$ and B6 mice are Th2 and Th1 prone, respectively (21). Thus, 
A
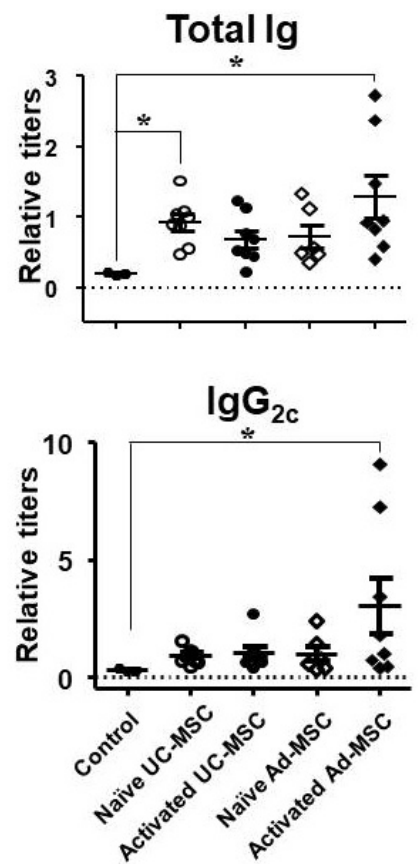

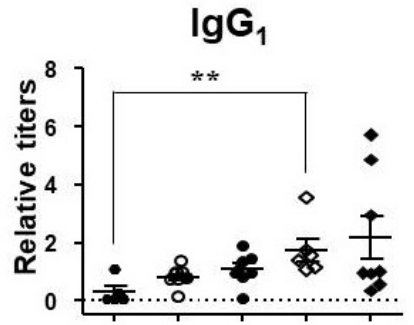

B
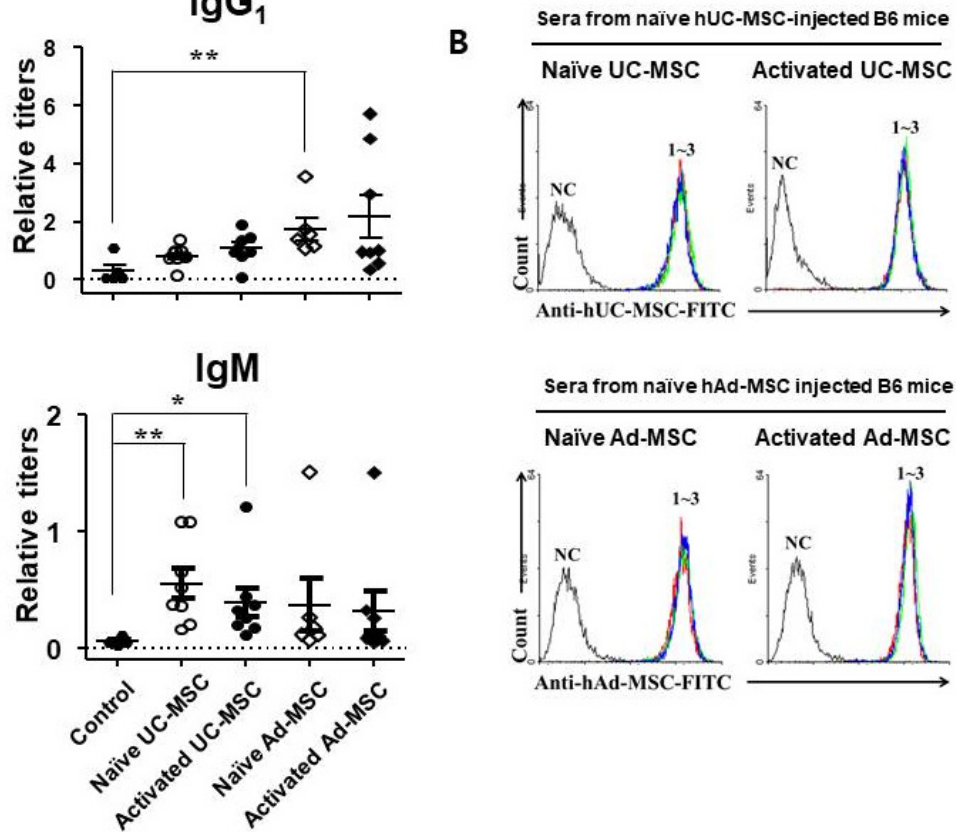

Fig. 5. Humoral immune responses against injected human MSCs in C57BL/6 mice. Mice were injected twice with naïve hUC-MSCs or hAd-MSCs on days 1 and 31, and blood samples were drawn on day 38. (A) Sera were obtained and subjected to ELISA for total Ig and each Ig isotype. (B) hUC-MSCs or hAd-MSCs were stained with the sera from mice injected with hUC-MSCs or hAd-MSCs, respectively, and subjected to flow cytometric analysis. ${ }^{*} p<0.05$ and ${ }^{* *} p<0.01$ vs. the control.

the humoral immune response in mice against hMSCs followed the Th1/Th2 paradigm. These results, together with the exaggerated secondary response and the germinal center formation reflect the characteristics of T-cell-dependent responses.

At least, several molecules expressed on the hMSC surface likely acted as xenogeneic antigens. The results that the sera surface-stained hMSCs (Fig. 3) support this assumption. Furthermore, sera from mice injected with naïve $\mathrm{hMSC}$ showed similar staining between naïve and activated hMSCs, whereas sera from mice injected with activated hMSCs showed more intense staining in activated than in the naïve hMSCs (Fig. 3, Supplementary Fig. S2, Table 2), which can be interpreted as that new proteins had expressed on the cell surface of hMSCs following activation and acted as additional antigens. In fact, IFN- $\gamma$, used for hMSC activation in the present study, promotes the expression of several surface molecules such as HLA-ABC and HLA-DR and secretory molecules in Ad-MSCs (18), B7-H1 in UC-MSCs (22), and ICAM-1 and VCAM-1 in Ad- and UC-MSCs (23).

For the production of antibodies to T-cell-dependent antigens, dendritic cells (DCs) engulf the antigens and present them to antigen-specific $\mathrm{T}$ cells, which then activate and help antigen-specific $\mathrm{B}$ cells proliferate and dif- ferentiate into plasma cells to secrete antigen-specific antibodies. MSCs across the species suppressively affect all of the players in this process, including DCs, T cells, and B cells. For example, MSCs inhibited the differentiation of DCs from their CD34+ progenitor cells or monocytes (24). The inhibited DCs expressed decreased levels of surface molecules such as CD86, CD83, CD80, HLA-DR, and CD40. MSCs administered in vivo downregulated expression of CCR7 and CD49d $\beta 1$ in DCs, thus inhibiting the homing of these cells to lymph nodes (25). hMSCs inhibited murine T-cell proliferation by secreting cyclooxygenase-2 (15). Regarding B cells, MSCs arrested the cell cycle in these cells (26) and inhibited differentiation of the cells into plasma cells (27). Thus, it would be natural to assume that a humoral immune response against hMSCs would not occur. However, the results of the present study are contradictory to this assumption. In fact, this "contradiction" has continuously been suggested by previous reports; cellular immune responses against intra-articularly injected hMSCs in horses (11) and intra-myocardially injected hMSCs in rats (12), local leukocyte infiltration at the injection site of hMSC in the putamen of mice (13). Repeated intravenous injection of hMSCs in female NZB/NZW F1 mice elicited antibody formation specific for the xenogeneic MSCs, as well as 
beneficial effects of delaying the onset of the disease (14). These contradictory results need to be explained, yet no explanation has been suggested in the previous reports. Unfortunately, we also have no experimental data to explain this apparent discrepancy.

Presumably, the activation status of the hMSCs could matter. MSCs exert immunomodulatory effects only when they are activated by pro-inflammatory cytokines such as IFN- $\gamma$ (28), TNF- $\alpha$ (29), and IL-1 $\beta$ (30) in an inflammatory environment, and the naive hMSCs injected into healthy mice might fail to exert immunomodulatory effects because they cannot be activated in the absence of inflammation. However, in the present study, even the ex-vivo IFN- $\gamma$-activated hMSCs did not show an immunosuppressive effect, similar to the naïve MSCs. Thus, activation status of the injected hMSCs was apparently not relevant.

Another concern is the incompatibility of cytokines or other factors that are needed for immunosuppression between humans and mice. For example, mouse IFN- $\gamma$, which is a principal cytokine for MSC priming, is not compatible with humans (15). Meanwhile, hMSC express indoleamine 2,3-dioxygenase (IDO) (31) and cyclooxygenase-2 (COX-2) (32), and these enzymes are important for immune modulation such as inhibition of $\mathrm{T}$ cell proliferation. IDO metabolizes tryptophan and its metabolites such as kynurenine, 3-hydroxykynurenine, and 3-hydroxyanthranilic acid is known to inhibit the proliferation of T cells (33). COX-2 exhibits its action by producing PGE2 (32). Both of these enzymes have been reported to be produced also in mouse MSCs and used for immune modulation (34). Altogether, human IL-10 and TGF- $\beta$, the major effector cytokines responsible for the immunosuppressive function of MSCs, act on mouse cells $(35,36)$. Thus, cytokine incompatibility between humans and mice does not appear to be a major cause of the failed suppression of the humoral immune response.

The number of live hMSCs in mouse lymphoid organs can be another possible explanation. In vitro inhibition of T-cell proliferation by hMSCs is apparent at a $1: 10$ ratio of MSCs to T cells; however, the effect is dose-dependent and becomes negligible at a $1: 400$ ratio $(15,20)$. Additionally, activated MSCs need proximity to affect B cells (37). Thus, a significant number of MSCs should be concentrated in lymphoid organs to exert their immunosuppressive effects. Although the number of hMSCs that reached the spleen and regional lymph nodes is unknown, we can surmise that the number is not substantial based on previous reports; hMSCs injected into normal mice or rats may or may not reach the spleen depending on the administration route, and even MSCs have reached the spleen, the frequency is low or very low (38). Another concern is the viability of hMSCs injected into mice. Even though some investigators reported long-term survival of hMSCs in mice, also reported are that majority of hMSCs disappear within $1 \sim 2$ weeks after injection into mice, regardless of the administration route $(39,40)$. Therefore, it is reasonable to assume that many of the administered hMSCs die early instead they accumulate in lymphoid organs. Thus, it is anticipated that the number of live $\mathrm{hMSC}$ in organs such as the spleen and lymph nodes are not enough to suppress the humoral immunes response.

The limitation of this study is that experiments have not been performed in disease animal models with vivid inflammation, in which the immune milieu could be different from those in healthy animals and thus the processes of humoral immune response might differ. It should be further elucidated whether the phenomena observed in this study would be recapitulated when hMSCs are administered in these animals.

In conclusion, although many preclinical studies in disease animal models have shown that hMSCs suppressed the immune and inflammatory responses of host animals, the results of the present study showed that hMSCs administered in healthy mice induced a strong humoral immune response characterized by typical $\mathrm{T}$ cell-dependent immunity. These results should be considered when designing preclinical experiments using hMSCs and interpreting the results from them, especially with repeated injections of hMSCs.

\section{Acknowledgments}

This research was supported exclusively by the Bio \& Medical Technology Development Program of the National Research Foundation (NRF) funded by the Ministry of Science, ICT \& Future Planning (NRF-2015M3A9E6028677). No any other financial sources support this study.

\section{Potential Conflict of Interest}

The authors have no conflicting financial interest.

\section{Supplementary Materials}

Supplementary data including four figures can be found with this article online at https://doi.org/10.15283/ijsc21116.

\section{References}

1. To K, Zhang B, Romain K, Mak C, Khan W. Synovium-derived mesenchymal stem cell transplantation in cartilage 
regeneration: a PRISMA review of in vivo studies. Front Bioeng Biotechnol 2019;7:314

2. Ansari AS, Yazid MD, Sainik NQAV, Razali RA, Saim AB, Idrus RBH. Osteogenic induction of Wharton's jelly-derived mesenchymal stem cell for bone regeneration: a systematic review. Stem Cells Int 2018;2018:2406462

3. $\mathrm{Hu} \mathrm{C}$, Zhao L, Li L. Current understanding of adiposederived mesenchymal stem cell-based therapies in liver diseases. Stem Cell Res Ther 2019;10:199

4. Cofano F, Boido M, Monticelli M, Zenga F, Ducati A, Vercelli A, Garbossa D. Mesenchymal stem cells for spinal cord injury: current options, limitations, and future of cell therapy. Int J Mol Sci 2019;20:2698

5. Le Blanc K, Rasmusson I, Sundberg B, Götherström C, Hassan $M$, Uzunel $M$, Ringdén $O$. Treatment of severe acute graft-versus-host disease with third party haploidentical mesenchymal stem cells. Lancet 2004;363:1439-1441

6. Álvaro-Gracia JM, Jover JA, García-Vicuña R, Carreño L, Alonso A, Marsal S, Blanco F, Martínez-Taboada VM, Taylor P, Martín-Martín C, DelaRosa O, Tagarro I, DíazGonzález F. Intravenous administration of expanded allogeneic adipose-derived mesenchymal stem cells in refractory rheumatoid arthritis (Cx611): results of a multicentre, dose escalation, randomised, single-blind, placebo-controlled phase Ib/IIa clinical trial. Ann Rheum Dis 2017;76:196-202

7. Zhang J, Lv S, Liu X, Song B, Shi L. Umbilical cord mesenchymal stem cell treatment for Crohn's disease: a randomized controlled clinical trial. Gut Liver 2018;12:7378

8. Schepers K, Fibbe WE. Unraveling mechanisms of mesenchymal stromal cell-mediated immunomodulation through patient monitoring and product characterization. Ann N Y Acad Sci 2016;1370:15-23

9. Prockop DJ, Oh JY, Lee RH. Data against a common assumption: xenogeneic mouse models can be used to assay suppression of immunity by human MSCs. Mol Ther 2017; 25:1748-1756

10. Buja LM, Vela D. Immunologic and inflammatory reactions to exogenous stem cells implications for experimental studies and clinical trials for myocardial repair. J Am Coll Cardiol 2010;56:1693-1700

11. Pigott JH, Ishihara A, Wellman ML, Russell DS, Bertone $\mathrm{AL}$. Investigation of the immune response to autologous, allogeneic, and xenogeneic mesenchymal stem cells after intra-articular injection in horses. Vet Immunol Immunopathol 2013;156:99-106

12. Grinnemo KH, Månsson A, Dellgren G, Klingberg D, Wardell E, Drvota V, Tammik C, Holgersson J, Ringdén O, Sylvén C, Le Blanc K. Xenoreactivity and engraftment of human mesenchymal stem cells transplanted into infarcted rat myocardium. J Thorac Cardiovasc Surg 2004; 127:1293-1300

13. Hwang JW, Lee NK, Yang JH, Son HJ, Bang SI, Chang JW, Na DL. A comparison of immune responses exerted following syngeneic, allogeneic, and xenogeneic trans- plantation of mesenchymal stem cells into the mouse brain. Int J Mol Sci 2020;21:3052

14. Choi EW, Lee HW, Shin IS, Park JH, Yun TW, Youn HY, Kim SJ. Comparative efficacies of long-term serial transplantation of syngeneic, allogeneic, xenogeneic, or CTLA4Igoverproducing xenogeneic adipose tissue-derived mesenchymal stem cells on murine systemic lupus erythematosus. Cell Transplant 2016;25:1193-1206

15. Kim JH, Lee YT, Hong JM, Hwang YI. Suppression of in vitro murine $\mathrm{T}$ cell proliferation by human adipose tissue-derived mesenchymal stem cells is dependent mainly on cyclooxygenase-2 expression. Anat Cell Biol 2013;46: 262-271

16. Jo CH, Kim OS, Park EY, Kim BJ, Lee JH, Kang SB, Lee JH, Han HS, Rhee SH, Yoon KS. Fetal mesenchymal stem cells derived from human umbilical cord sustain primitive characteristics during extensive expansion. Cell Tissue Res 2008;334:423-433

17. Kim JH, Lee YT, Oh K, Cho J, Lee DS, Hwang YI. Paradoxical effects of human adipose tissue-derived mesenchymal stem cells on progression of experimental arthritis in SKG mice. Cell Immunol 2014;292:94-101

18. Kim JH, Jo CH, Kim HR, Hwang YI. Comparison of immunological characteristics of mesenchymal stem cells from the periodontal ligament, umbilical cord, and adipose tissue. Stem Cells Int 2018;2018:8429042

19. Martin RM, Brady JL, Lew AM. The need for IgG2c specific antiserum when isotyping antibodies from C57BL/6 and NOD mice. J Immunol Methods 1998;212:187-192

20. Stevens TL, Bossie A, Sanders VM, Fernandez-Botran R, Coffman RL, Mosmann TR, Vitetta ES. Regulation of antibody isotype secretion by subsets of antigen-specific helper T cells. Nature 1988;334:255-258

21. Mills CD, Kincaid K, Alt JM, Heilman MJ, Hill AM. M-1/M-2 macrophages and the Th1/Th2 paradigm. J Immunol 2000;164:6166-6173

22. Jang IK, Jung HJ, Noh OK, Lee DH, Lee KC, Park JE. B7-H1-mediated immunosuppressive properties in human mesenchymal stem cells are mediated by STAT-1 and not PI3K/Akt signaling. Mol Med Rep 2018;18:1842-1848

23. Wang Q, Yang Q, Wang Z, Tong H, Ma L, Zhang Y, Shan F, Meng Y, Yuan Z. Comparative analysis of human mesenchymal stem cells from fetal-bone marrow, adipose tissue, and Warton's jelly as sources of cell immunomodulatory therapy. Hum Vaccin Immunother 2016;12:85-96

24. Nauta AJ, Kruisselbrink AB, Lurvink E, Willemze R, Fibbe WE. Mesenchymal stem cells inhibit generation and function of both $\mathrm{CD} 34^{+}$-derived and monocyte-derived dendritic cells. J Immunol 2006;177:2080-2087

25. Chiesa S, Morbelli S, Morando S, Massollo M, Marini C, Bertoni A, Frassoni F, Bartolomé ST, Sambuceti G, Traggiai E, Uccelli A. Mesenchymal stem cells impair in vivo T-cell priming by dendritic cells. Proc Natl Acad Sci U S A 2011;108:17384-17389

26. Corcione A, Benvenuto F, Ferretti E, Giunti D, Cappiello V, Cazzanti F, Risso M, Gualandi F, Mancardi GL, Pistoia 
V, Uccelli A. Human mesenchymal stem cells modulate B-cell functions. Blood 2006;107:367-372

27. Franquesa $M$, Mensah FK, Huizinga $R$, Strini T, Boon L, Lombardo E, DelaRosa O, Laman JD, Grinyó JM, Weimar W, Betjes MG, Baan CC, Hoogduijn MJ. Human adipose tissue-derived mesenchymal stem cells abrogate plasmablast formation and induce regulatory $\mathrm{B}$ cells independently of T helper cells. Stem Cells 2015;33:880-891

28. Kim DS, Jang IK, Lee MW, Ko YJ, Lee DH, Lee JW, Sung $\mathrm{KW}$, Koo HH, Yoo KH. Enhanced immunosuppressive properties of human mesenchymal stem cells primed by interferon- $\gamma$. EBioMedicine 2018;28:261-273

29. Putra A, Ridwan FB, Putridewi AI, Kustiyah AR, Wirastuti K, Sadyah NAC, Rosdiana I, Munir D. The role of TNF- $\alpha$ induced MSCs on suppressive inflammation by increasing TGF- $\beta$ and IL-10. Open Access Maced J Med Sci 2018;6: $1779-1783$

30. Wu TY, Liang YH, Wu JC, Wang HS. Interleukin-1 $\beta$ enhances umbilical cord mesenchymal stem cell adhesion ability on human umbilical vein endothelial cells via LFA-1/ICAM-1 interaction. Stem Cells Int 2019;2019: 7267142

31. Meisel R, Zibert A, Laryea M, Göbel U, Däubener W, Dilloo D. Human bone marrow stromal cells inhibit allogeneic T-cell responses by indoleamine 2,3-dioxygenase-mediated tryptophan degradation. Blood 2004;103:4619-4621

32. Aggarwal S, Pittenger MF. Human mesenchymal stem cells modulate allogeneic immune cell responses. Blood 2005; 105:1815-1822

33. Bauer TM, Jiga LP, Chuang JJ, Randazzo M, Opelz G, Terness P. Studying the immunosuppressive role of indole- amine 2,3-dioxygenase: tryptophan metabolites suppress rat allogeneic T-cell responses in vitro and in vivo. Transpl Int 2005;18:95-100

34. English K, Barry FP, Field-Corbett CP, Mahon BP. IFN-gamma and TNF-alpha differentially regulate immunomodulation by murine mesenchymal stem cells. Immunol Lett 2007;110:91-100

35. Massagué J, Like B. Cellular receptors for type beta transforming growth factor. Ligand binding and affinity labeling in human and rodent cell lines. J Biol Chem 1985;260: 2636-2645

36. Tan JC, Indelicato SR, Narula SK, Zavodny PJ, Chou CC. Characterization of interleukin-10 receptors on human and mouse cells. J Biol Chem 1993;268:21053-21059

37. Luk F, Carreras-Planella L, Korevaar SS, de Witte SFH, Borràs FE, Betjes MGH, Baan CC, Hoogduijn MJ, Franquesa $M$. Inflammatory conditions dictate the effect of mesenchymal stem or stromal cells on B cell function. Front Immunol 2017;8:1042

38. Leibacher J, Henschler R. Biodistribution, migration and homing of systemically applied mesenchymal stem/stromal cells. Stem Cell Res Ther 2016;7:7

39. Braid LR, Wood CA, Wiese DM, Ford BN. Intramuscular administration potentiates extended dwell time of mesenchymal stromal cells compared to other routes. Cytotherapy 2018;20:232-244

40. Toupet K, Maumus M, Peyrafitte JA, Bourin P, van Lent PL, Ferreira R, Orsetti B, Pirot N, Casteilla L, Jorgensen C, Noël D. Long-term detection of human adipose-derived mesenchymal stem cells after intraarticular injection in SCID mice. Arthritis Rheum 2013;65:1786-1794 